\title{
Detection of Surface-exposed Epitopes on Chlamydia trachomatis by Immune Electron Microscopy
}

\author{
By BOBBIE ANN COLLETT, ${ }^{1}$ WILBERT J. NEWHALL, V, $1,2 *$ \\ RALPH A. JERSILD, JR ${ }^{3}$ AND ROBERT B. JONES ${ }^{1,2}$ \\ ${ }^{1}$ Department of Microbiology and Immunology, ${ }^{2}$ Department of Medicine and ${ }^{3}$ Department of \\ Anatomy, Indiana University School of Medicine, Indianapolis 46223, USA
}

(Received 19 July 1988; accepted 30 September 1988)

\begin{abstract}
The cell surfaces of two Chlamydia trachomatis serovars were explored by immune electron microscopy with monoclonal antibodies that recognize a number of chlamydial outermembrane components. Species, subspecies and serovar-reactive epitopes on the major outermembrane protein (MOMP) of a lymphogranuloma venereum biovar strain, $\mathrm{L}_{2} / 434 / \mathrm{Bu}$, and a trachoma biovar strain, $\mathrm{F} / \mathrm{UW}-6 / \mathrm{Cx}$, were exposed on the surfaces of both elementary bodies (EBs) and reticulate bodies (RBs). Three epitopes on MOMP were inaccessible on EBs and RBs of both strains. These included a genus-reactive, species-reactive, and a subspecies-reactive epitope. In contrast, genus-specific epitopes on lipopolysaccharide (LPS) were not detected on the EB surface, but were clearly expressed on $\mathrm{RBs}$ of both $\mathrm{L}_{2} / 434 / \mathrm{Bu}$ and $\mathrm{F} / \mathrm{UW}-6 / \mathrm{Cx}$ chlamydiae. Antibodies specific for the $60 \mathrm{kDa}$ and $12 \mathrm{kDa}$ 'cysteine-rich' outer-membrane proteins did not react with surface epitopes on either EBs or RBs. These data provide evidence that MOMP is a major surface antigen of both morphological forms, whereas some portions of the LPS molecule are exposed on the RB surface but become inaccessible to antibody after conversion to the infectious EB form.
\end{abstract}

\section{INTRODUCTION}

The chlamydial surface appears to play a role in the attachment to and the induction of phagocytosis by non-professional phagocytes (Byrne \& Moulder, 1978; Eissenberg et al., 1983) and possibly functions in the prevention of phagosome-lysosome fusion (Eissenberg et al., 1981, 1983). All of these events are necessary for the successful production of infectious progeny particles. Current evidence suggests that the chlamydial cell envelope and its components may influence each of these events. Infectious EBs, EB envelopes, and UV-treated EBs attach to and are ingested by host cells, whereas heat-denatured EBs or EB envelopes exhibit decreased attachment (Byrne \& Moulder, 1978; Friis, 1972; Kuo \& Grayston, 1976; Levy \& Moulder, 1982). The rate of chlamydial ingestion by non-professional phagocytes is nearly 100 times greater than that of other small particulates and has thus been termed parasite-specified (Byrne \& Moulder, 1978). Internalized EBs or EB envelopes apparently avoid the host defence mechanism of phagolysosome fusion, whereas heat-denatured EBs or EB envelopes do not (Eissenberg et al., 1983; Friis, 1972; Lawn et al., 1973). These data suggest the presence of a protein component(s) in the EB envelope, possibly exposed at the surface, whose native structure is essential to the successful infection of host cells.

In addition to serving functional roles in pathogenesis, the chlamydial surface also appears to be a primary target of the host immune system. Preincubation of EBs with specific antibody

\footnotetext{
Abbreviations: EB, elementary body; RB, reticulate body; LPS, lipopolysaccharide; IEM, immunocytochemical method for electron microscopy; MOMP, major outer-membrane protein; PAG, protein-A-conjugated colloidal gold particles; RAM, rabbit anti-mouse.
} 
decreases their ability to attach to host cells (Levy \& Moulder, 1982), decreases the internalization of those chlamydia that do attach (Ward \& Murray, 1984), increases chlamydial susceptibility to phagolysosome fusion (Friis, 1972), and may further neutralize EBs by other unknown post-internalization mechanisms (Caldwell \& Perry, 1982). Neutralization of chlamydial infectivity has been observed with eye secretions and plasma from children with active trachoma (Barenfanger \& MacDonald, 1974). In a murine pneumonia model that uses the mouse pneumonitis strain of $C$. trachomatis, resistance to reinfection is observed after passive transfer of immune mouse serum (Williams et al., 1982). In addition, murine antisera and a number of monoclonal antibodies specific for chlamydial outer-membrane epitopes appear to exhibit neutralizing ability in tissue culture systems (Caldwell \& Perry, 1982; Clark et al., 1982; Lucero \& Kuo, 1985; Peeling et al., 1984; Wenman \& Meuser, 1986). Many of these antibodies have specificity for MOMP, which is one of the few proteins that have been demonstrated to be surface exposed by radioiodination methods (Caldwell et al., 1981). The surface exposure of other chlamydial outer-membrane components has not been adequately documented.

To assess the surface exposure of epitopes that are located on chlamydial LPS and outermembrane proteins, including MOMP and the $60 \mathrm{kDa}$ and $12 \mathrm{kDa}$ 'cysteine-rich' EBassociated proteins, we have evaluated anti-chlamydial monoclonal and polyclonal antibodies in an immunocytochemical method for electron microscopy (IEM) that makes use of staphylococcal protein-A-conjugated colloidal gold particles (PAG) as electron-dense markers. Colloidal gold has many properties that make it a useful IEM immunolabel for microbiological specimens (Beesley, 1984), and it has been used successfully to label antibody-accessible epitopes on the surfaces of bacterial cells (Robinson et al., 1984), capsules (Mouton \& Lamonde, 1984), pili (Beesley, et al., 1984; Robinson et al., 1984), and viruses (Beesley, 1984). We report here the surface exposure of species-, subspecies- and serovar-reactive epitopes and the inaccessibility of some genus-reactive epitopes on both RBs and EBs of two C. trachomatis serovars.

\section{METHODS}

Preparation of organisms. C. trachomatis was cultivated by established methods (Newhall et al., 1986) in HeLa 229 cells. Strains $\mathrm{L}_{2} / 434 / \mathrm{Bu}$ and $\mathrm{F} / \mathrm{UW}-6 / \mathrm{Cx}$, originally obtained from C.-C. Kuo, University of Washington, Seattle, Washington, USA, were harvested by a modification of the Renografin purification procedure (Caldwell et al., 1981) at the end of the developmental cycle: 48 and $72 \mathrm{~h}$, respectively. Infected cells were ruptured with sterile glass beads, suspended in Hanks' balanced salt solution, sonicated for 5-10 s, and centrifuged at $500 \mathrm{~g}$ to remove gross cell debris. The resulting supernatant was layered over a discontinuous gradient consisting of $2 \mathrm{ml}$ $52 \%(\mathrm{v} / \mathrm{v})$ and $8 \mathrm{ml} \mathrm{35 \%}$ Renografin 76 (diatrizoate meglumine and diatrizoate sodium, E. R. Squibb \& Sons)

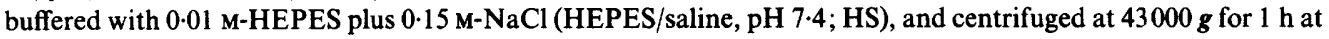
$4{ }^{\circ} \mathrm{C}$ in a Beckman SW25.1 rotor. The band located at the 35-52\% interface was collected, combined with $2 \mathrm{ml}$ $10 \%$ HS-buffered Renografin and layered over a second discontinuous gradient consisting of $5 \mathrm{ml} 52 \%, 11 \mathrm{ml} 44 \%$ and $10 \mathrm{ml} 40 \%$ Renografin in $\mathrm{HS}$; this was centrifuged at $43000 \mathrm{~g}$ for $1 \mathrm{~h}$ at $4{ }^{\circ} \mathrm{C}$. Chlamydiae were separated into reasonably distinct RB and EB populations based on a difference in density. Purified EBs and RBs were collected from the $44-52 \%$ interface and the $40-44 \%$ interface, respectively, as described previously (Barbour et al., 1982), and washed in cold phosphate-buffered saline (PBS; $145 \mathrm{mM}-\mathrm{NaCl}, 10 \mathrm{~mm}$-sodium phosphate, $\mathrm{pH} 7.4$ ). Purified chlamydiae were either used immediately or were fixed with $0.5 \%(\mathrm{v} / \mathrm{v})$ formaldehyde (electron microscopy grade, $10 \%$ stock, Polysciences Inc.) in PBS and stored at $4{ }^{\circ} \mathrm{C}$ until used (up to 3 months).

Total protein content of chlamydial suspensions was determined by a fluorimetric assay (Benson \& Hare, 1975) using Fluoraldehyde (Pierce Chemical Company). Bovine serum albumin (BSA) was used as a standard. Chlamydial suspensions used in this study had a total protein concentration range of $1.5-2.5 \mathrm{mg} \mathrm{ml}^{-1}$.

Immunoreagents. PAG with a $5 \mathrm{~nm}$ mean diameter (Janssen) served as a particulate electron-dense antibodyspecific marker. Monoclonal antibodies specific for various chlamydial components have been characterized previously (Batteiger et al., 1986; Newhall \& Basinski, 1986; Newhall et al., 1986; Wilde et al., 1986) and were in the form of ascites fluids. Polyclonal antisera were generated in hyperimmunized mice using purified chlamydial proteins (Newhall \& Basinski, 1986) as the immunogen. All monoclonal antibodies were tested for the ability to bind staphylococcal protein $\mathrm{A}$. When a monoclonal antibody with poor protein-A-binding capacity was used, a rabbit anti-mouse (RAM) immunoglobulin antiserum (Accurate Chemicals) that reacts very well with protein $A$ was utilized to allow attachment of the PAG probe. Negative controls were provided by a murine ascites containing a monoclonal antibody specific for a protein II (P. IIc) of strain F62 of Neisseria gonorrhoeae (Newhall et al.,, 1985) and normal Balb/c mouse serum. 
Immunocytochemistry. Chlamydial suspensions $(5 \mu \mathrm{l})$ were adsorbed to the coated side of collodion-surfaced, carbon-stabilized, copper grids for $3 \mathrm{~min}$. This suspension was aspirated, and the grids were incubated for $5 \mathrm{~min}$ with $5 \mu \mathrm{l}$ PBS containing $0.1 \%(\mathrm{w} / \mathrm{v}) \mathrm{BSA}, 1 \%(\mathrm{w} / \mathrm{v})$ glycine and $20 \mathrm{mM}^{-\mathrm{NaN}_{3}}$ (PBSAG) to block non-specific protein-binding sites. The grids were then floated on a drop of antibody solution for $30 \mathrm{~min}$ at $37^{\circ} \mathrm{C}$ in a moist chamber, and washed 10 times with PBSA (PBSAG without $1 \%$ glycine), allowing each wash to remain on the grid for $5 \mathrm{~s}$. When a monoclonal antibody with poor protein-A-binding capacity was used, an additional $30 \mathrm{~min}$ incubation at $37^{\circ} \mathrm{C}$ with diluted RAM was included in the procedure at this point, followed by washing as previously described. Grids were then incubated in a solution of PAG for $30 \mathrm{~min}$ at $37^{\circ} \mathrm{C}$ in the moist chamber. The grids were again washed, incubated for $3 \mathrm{~min}$ at $25^{\circ} \mathrm{C}$ with $5 \mu 10.05 \%(\mathrm{w} / \mathrm{v})$ aqueous solution of BSA, pH 7.0, aspirated to dryness, and viewed with a Philips EM400 transmission electron microscope within $2 \mathrm{~h}$. Each antibody was tested on at least two different days and all grids were evaluated by scanning multiple random fields. No less than 100 individual bacteria were randomly selected and the number of bound PAG particles on each was determined. The background binding was determined by calculating the average number of PAG particles in 10 random $265 \times 265 \mathrm{~nm}$ squares for EB experiments, and in 10 random $700 \times 700 \mathrm{~nm}$ squares for RB experiments. These areas are roughly equal to those of an EB with a $300 \mathrm{~nm}$ diameter and an RB with an $800 \mathrm{~nm}$ diameter.

The effect of PAG and antibody concentration was explored through titration experiments. Serial dilutions of monoclonal antibody ( 1 in 10,1 in 50,1 in 200,1 in 800,1 in 3200 and 1 in $12800, v / v)$ were prepared and run in the above IEM system. The effect of PAG concentration was similarly tested using a surface-reactive monoclonal antibody $\left(\mathrm{L}_{1} / 2 / \mathrm{C} 5 / \mathrm{B} 8\right)$.

PAG and antibodies were diluted in PBSA. Ascites fluids, whole antisera, RAM and PAG were each routinely used at a 1 in 50 dilution, and the bacteria-coated grid surfaces were incubated on $20 \mu 1$ droplets of these solutions.

Thin section transmission electron microscopy. Unfixed, purified chlamydiae in PBS were fixed in suspension with $3 \%(\mathrm{v} / \mathrm{v})$ glutaraldehyde at $4{ }^{\circ} \mathrm{C}$ overnight. The samples were then sedimented in a microfuge (Fisher Microcentrifuge model 235B) for $3 \mathrm{~min}$. The cell pellet was carefully dislodged from the tube wall and subjected to three changes of cold $0.1 \mathrm{M}$-sodium phosphate buffer, $\mathrm{pH} 7.4(\mathrm{~PB})$, post-fixed in $1 \%(\mathrm{w} / \mathrm{v})$ osmium tetroxide in PB for $1 \mathrm{~h}$, and dehydrated in a graded series of ethanol. Specimens were then infiltrated with propylene oxide and embedded in Spurr resin. Thin sections were stained with uranyl acetate and lead citrate.

\section{RESULTS}

\section{Purified chlamydiae}

Thin-section transmission electron micrographs of typical preparations of EBs and RBs after centrifugation to yield pellets of organisms are shown in Fig. 1. The EB preparation consisted primarily of intact EBs and a smaller population of other chlamydial forms including RBs and some forms that were intermediate between EBs and RBs. The RB preparation contained predominantly RBs, based on size and appearance of cytoplasmic contents. A few EBs and intermediate forms were also present. The majority of the chlamydial forms in both preparations were intact. The general quality of the preparations and the distribution of the different chlamydial forms were very similar for both the $F$ and $L_{2}$ serovar strains.

When the chlamydial suspensions were viewed by transmission electron microscopy after adsorption to the electron microscopy grids, two distinct morphological forms were observed (Fig. 2). The predominant form in EB preparations was circular with a diameter of about $300 \mathrm{~nm}$ and displayed significant variation in electron density, providing a 'shrivelled pea' appearance. Based on the number and size of these particles we concluded that they represent intact EBs. In RB preparations the predominant form was larger than EBs with a diameter of $600-1000 \mathrm{~nm}$. Variation in electron density was observed within these bacteria, suggesting the presence of cytoplasmic contents; however, this variation was less than that observed within the EB. Thus, based on these observations and data from thin sections (as in Fig. 1), we conclude that most of these forms are intact RBs and condensing forms.

\section{Immunocytochemistry}

To provide a semi-quantitative measure of the reactivity of a monoclonal antibody with the chlamydial surface, a positive result was recorded when more than $90 \%$ of bacteria of a particular form displayed more than 50 PAG bound over their surfaces after subtracting background. The reaction was considered negative when the average number of bound PAG per organism was less than 10 . Representative micrographs of positive and negative reactions with both EBs and RBs are shown in Fig. 2. The results for all the antibodies tested are given in Table 1 . 

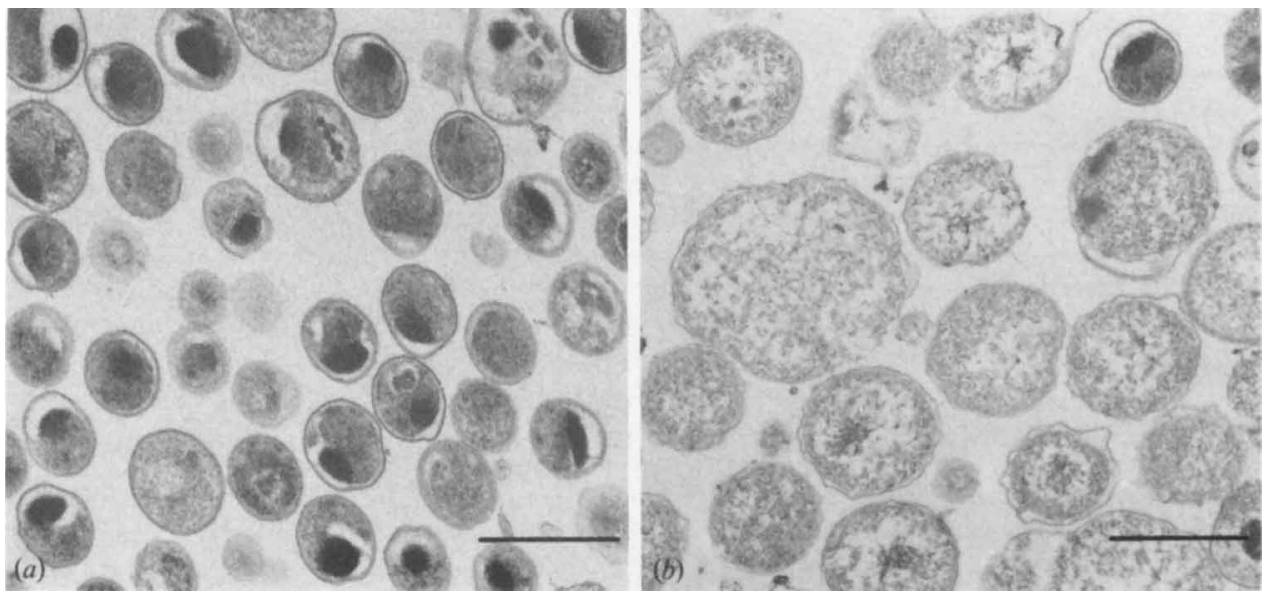

Fig. 1. Thin-section transmission electron micrographs of $\mathrm{L}_{2} / 434 / \mathrm{Bu}$ chlamydia harvested at $48 \mathrm{~h}$ postinfection and purified on Renografin gradients. (a) EB preparation, (b) RB preparation. Bars, $0.5 \mu \mathrm{m}$.

Table 1. Surface reactivity of anti-chlamydial monoclonal antibodies

\begin{tabular}{|c|c|c|c|c|c|c|}
\hline \multirow[b]{3}{*}{ Antibody } & & & \multicolumn{4}{|c|}{ IEM reactivity } \\
\hline & \multicolumn{2}{|r|}{ Specificity } & \multicolumn{2}{|c|}{ F/UW-6/Cx } & \multicolumn{2}{|c|}{$\mathrm{L}_{2} / 434 / \mathrm{Bu}$} \\
\hline & Antigen & Strains or serovars & EB & $\mathbf{R B}$ & EB & $\mathrm{RB}$ \\
\hline Normal mouse serum & - & - & - & - & $-^{*}$ & $-*$ \\
\hline $53 \mathrm{~A} 5-4$ & Protein II & F62 of Neisseria gonorrhoeae & - & - & $-*$ & $-^{*}$ \\
\hline M.1/2E11/D6 & MOMP & Genus & - & - & $-^{*}$ & $-{ }^{*}$ \\
\hline $\mathrm{L} 1 / 2 / \mathrm{C} 5 / \mathrm{B} 8$ & MOMP & Species (C. trachomatis) & + & + & $t^{*}$ & $t^{*}$ \\
\hline $\mathrm{H} / 31 / 6 \mathrm{~B} 11 / \mathrm{C} 5$ & MOMP & Species (C. trachomatis) & - & - & $-{ }^{*}$ & $-^{*}$ \\
\hline $\mathrm{F} / 22 / 4 \mathrm{C} 11 / 2 \mathrm{E} 4$ & MOMP & Species (except B and Ba) & + & + & + & + \\
\hline $\mathrm{L} 2 / 57 / \mathrm{B} 1 / 2 \mathrm{~A}$ & MOMP & $\mathrm{B}, \mathrm{Ba}, \mathrm{D}, \mathrm{E}, \mathrm{L} 1, \mathrm{~L} 2$ & - & - & + & + \\
\hline $\mathrm{Ba} / 243 / 5 \mathrm{G} 4 / \mathrm{G} 7$ & MOMP & $\mathrm{B}, \mathrm{Ba}, \mathrm{L} 2$ & - & - & + & + \\
\hline $\mathrm{M} .1 / 3 \mathrm{E} 11 / \mathrm{D} 3$ & MOMP & $\mathrm{A}, \mathrm{C}, \mathrm{H}, \mathbf{I}, \mathbf{J}, \mathrm{K}, \mathrm{L} 1, \mathrm{~L} 2, \mathrm{~L} 3$ & - & - & - & - \\
\hline $\mathrm{G} / 238 / 4 \mathrm{G} 10 / \mathrm{G} 6$ & MOMP & $\mathrm{F}, \mathrm{G}$ & + & + & - & - \\
\hline $\mathrm{L} 2 / 1 \mathrm{~A} 5 / 3 \mathrm{C} 3$ & MOMP & $\mathrm{L} 2$ & - & - & + & + \\
\hline $\mathrm{F} / 221 / 6 \mathrm{C} 2 / \mathrm{C} 2$ & MOMP & $\mathbf{F}$ & + & + & - & - \\
\hline $60 \mathrm{~K} / 4 \mathrm{E} 9 / \mathrm{B} 10$ & $60 \mathrm{kDa}$, epitope $\mathrm{A}$ & Species (C. trachomatis) & - & - & - & - \\
\hline $60 \mathrm{~K} / 2 \mathrm{G} 11 / \mathrm{B} 5$ & $60 \mathrm{kDa}$, epitope $\mathrm{B}$ & Species (C. trachomatis) & - & - & - & - \\
\hline $60 \mathrm{~K} / 5 \mathrm{~B} 9 / \mathrm{E} 4$ & $60 \mathrm{kDa}$, epitope $\mathrm{C}$ & Species (C. trachomatis) & - & - & - & - \\
\hline Mouse anti-60 K & $60 \mathrm{kDa}$ & Species (C. trachomatis) & - & - & $-{ }^{*}$ & $-^{*}$ \\
\hline $12 \mathrm{~K} / 5 \mathrm{~A} 11 / \mathrm{B} 9$ & $15 \mathrm{kDa}$ and $29 \mathrm{kDa}$ & Genus & - & - & $-^{*}$ & $-^{*}$ \\
\hline $47 \mathrm{~A} 2$ & LPS & Genus & - & + & $-{ }^{*}$ & $t^{*}$ \\
\hline $\mathrm{L} 2 / 6 / \mathrm{A} 11 / \mathrm{G} 3 / \mathrm{G} 4$ & LPS & Genus & - & + & - & + \\
\hline $\mathrm{H} / 31 / 5 \mathrm{G} 6 / \mathrm{G} 11 / \mathrm{B} 10$ & $62 \mathrm{kDa}$ & Species & - & - & $-^{*}$ & $-*$ \\
\hline $12 \mathrm{~K} / 4 \mathrm{~F} 5 / \mathrm{B} 11 / \mathrm{E} 6$ & $12 \mathrm{kDa}$ & Trachoma biovar & - & - & - & - \\
\hline
\end{tabular}

* Reactivity of formalin-fixed chlamydia was confirmed with chlamydia that were not fixed.

Fig. 2. Transmission electron micrographs of purified $\mathrm{L}_{2} / 434 / \mathrm{Bu}$ EBs and $\mathrm{RBs}$ after reaction with monoclonal antibodies specific for different outer-membrane components followed by PAG. For each antibody a field is shown that is representative of the reactions observed. $(a, b)$ Chlamydia incubated with a monoclonal antibody specific for a protein II of $N$. gonorrhoeae. This antibody served as a control for non-specific binding. $(c, d)$ Chlamydia incubated with a monoclonal antibody specific for an epitope located on the $60 \mathrm{kDa}$ 'cysteine-rich' outer-membrane protein. (e) Chlamydial EBs incubated with a monoclonal antibody specific for a species-reactive epitope on MOMP. $(f)$ Chlamydial RBs incubated with a monoclonal antibody specific for a genus-reactive epitope on lipopolysaccharide. $(a),(c)$ and $(e)$ illustrate fields containing multiple EBs. $(b),(d)$ and $(f)$ illustrate individual RBs. Bars, $0.5 \mu \mathrm{m}$. 

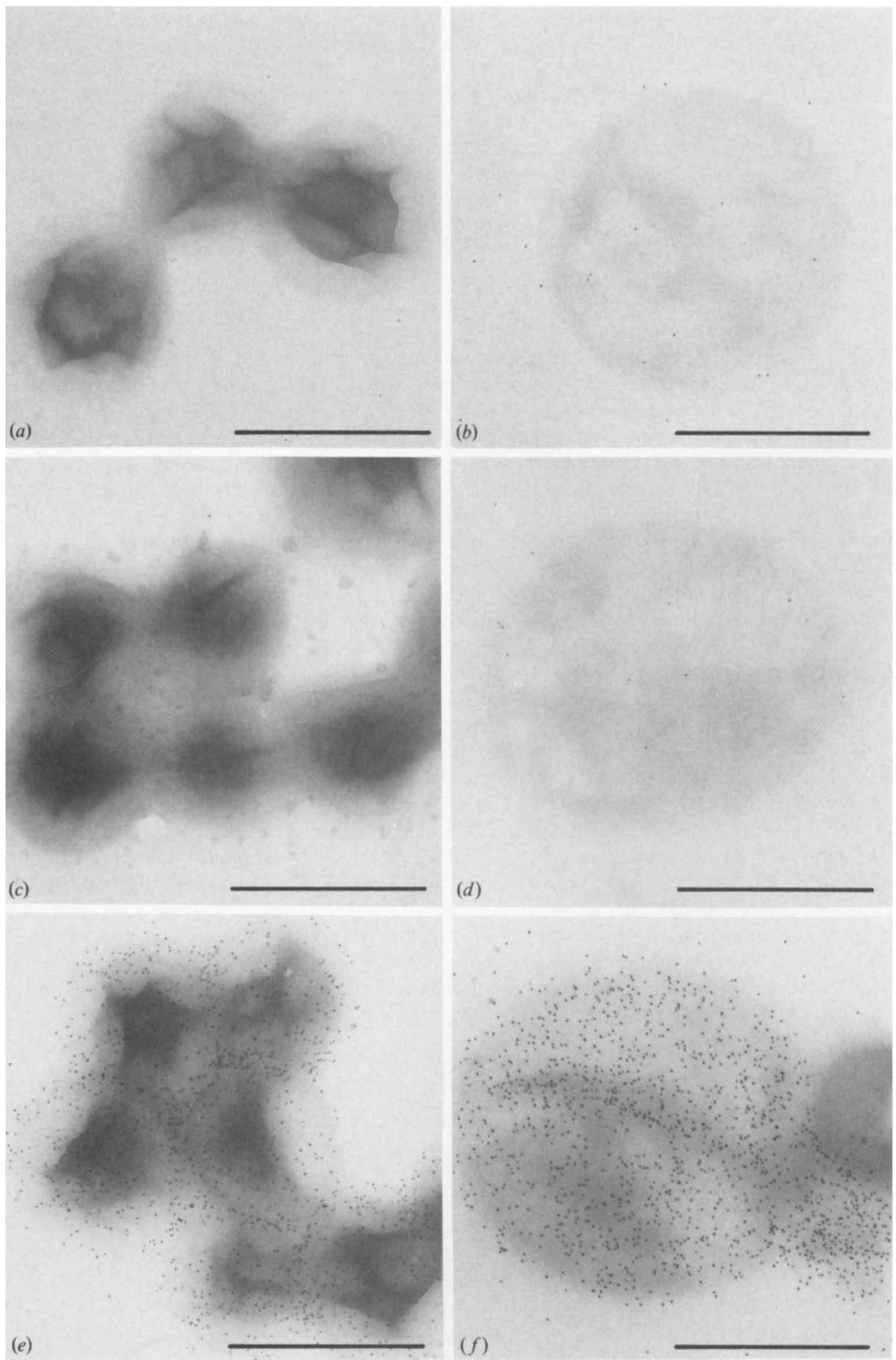
To provide a negative control in each experiment, the adsorbed chlamydia were probed with an ascites fluid containing monoclonal antibody specific for a protein II of Neisseria gonorrhoeae (Newhall et al., 1985). Very little PAG binding was observed either in the background or on the chlamydia (Fig. 2). Two types of reactions were observed with antibodies specific for MOMP. A genus-specific antibody, one of the species-specific antibodies, and one of the subspeciesspecific antibodies demonstrated no surface reactivity with either strain. In contrast, considerable surface binding was observed on both the EB and RB forms by the remaining MOMP-specific antibodies that possess species, various subspecies, and serovar specificities. Thus, MOMP expresses a range of epitopes on the outer-membrane surface. We have recently identified 10 additional genus-specific anti-MOMP antibodies that did not react with intact chlamydia in a radioimmunoassay that uses whole EBs as antigens (W. J. Newhall, unpublished). These data suggest that such conserved epitopes may be located on non-surfaceexposed regions of the protein.

Two other proteins known to be located in the outer membrane, the $60 \mathrm{kDa}$ and $12 \mathrm{kDa}$ proteins, were also tested for surface exposure with specific monoclonal antibodies. Antibodies specific for each of three distinct epitopes of the $60 \mathrm{kDa}$ protein (W. J. Newhall, unpublished), as well as an antiserum from a mouse hyperimmunized with purified $60 \mathrm{kDa}$ from serovar $\mathrm{F}$ all failed to react with the surfaces of bacteria from either serovar. An antibody specific for the $12 \mathrm{kDa}$ 'cysteine-rich' protein of trachoma biovar strains of $C$. trachomatis also did not react with the surface. Another antibody tested recognizes two different proteins in $C$. trachomatis strains. One of these has a conserved molecular mass of about $15 \mathrm{kDa}$ in all strains that we have examined, including two Chlamydia psittaci strains. The other varies among the serovars and has an estimated molecular mass of $29 \mathrm{kDa}$ in the $\mathrm{L}_{2}$ serovar and about $26 \mathrm{kDa}$ in the $\mathrm{F}$ serovar. These proteins correspond to those described by Hackstadt (1986) and Wenman \& Meuser (1986) that exhibit host-cell adhesin characteristics. This antibody did not bind to the chlamydial surface. We also tested an antibody specific for a $62 \mathrm{kDa}$ protein and found no surface reactivity. This protein is the same as the $62 \mathrm{kDa}$ protein against which humans make an antibody response during genital chlamydial infection (Newhall et al., 1982).

Another outer-membrane component that we evaluated with this method was the chlamydial LPS. Two antibodies were tested that were specific for a molecule analogous to the LPS described by Caldwell \& Hitchcock (1984). Each antibody exhibited binding to the RB form of both the serovars tested; the surfaces of EBs did not exhibit binding.

To evaluate the potential perturbing effects of formaldehyde fixation on the antigenic structure of the surface, selected antibodies which either had given a negative result or had reacted with $\mathrm{RBs}$ but not EBs were retested using freshly harvested unfixed organisms as the antigen. The use of unfixed organisms had no effect on the results obtained. Another possibility was that some cell drying may have occurred during grid processing, thereby altering surface antigens. However, in all experiments attempts were made to keep air drying of chlamydiaassociated grid surfaces to a minimum during the labelling procedure.

\section{DISCUSSION}

Information regarding the surface exposure of outer-membrane components of $C$. trachomatis has been derived by the use of extrinsic radio-iodination of proteins (Caldwell et al., 1981; Salari $\&$ Ward, 1981), cleavage of surface proteins with proteases (Hackstadt \& Caldwell, 1985), by microimmunofluorescence (Wang \& Grayston, 1971), and most recently by immunogold staining (Kuo \& Chi, 1987). These methods have demonstrated that MOMP is exposed at the chlamydial surface.

Our laboratory has recently evaluated a fairly extensive panel of MOMP-specific monoclonal antibodies for their ability to bind to purified EBs in a radioimmunoassay (Batteiger et al., 1986; Newhall et al., 1986). In an evaluation of antibodies having serovar, subspecies, species and genus specificities, all but the genus-specific, one of the species-specific, and one of the subspecies-specific anti-MOMP antibodies reacted with the EB preparations. Identical results were derived when these antibodies were assessed by microimmunofluorescence (W. J. Newhall, unpublished). Such data might be interpreted as indicating the surface exposure of 
these epitopes. However, electron microscopic evaluation of the purified EB preparations used for those studies indicated that although the majority of material was EBs, a small amount of RBs, other chlamydial forms, as well as membrane fragments of unknown origin were also present. Thus, other possible explanations for the binding of the monoclonal antibodies are possible. For example, some of the antibodies may recognize epitopes expressed only on certain morphological forms, on exposed regions of the underside of the outer membrane in broken cells and membrane fragments, and on intracellular antigens that may be liberated due to lysis of some chlamydia after purification. The goal of the present study was to develop a method of evaluating the surface exposure of chlamydial outer-membrane components on individual organisms, thereby eliminating many of the drawbacks of the radioimmunoassay, microimmunofluorescence and radio-iodination methods.

Previous antigenic analyses of the chlamydial MOMP have demonstrated serovar-, subspecies- and species-reactive epitopes on this protein. These findings correlate with the earlier antigenic classification of chlamydia by microimmunofluorescence (Wang \& Grayston, 1971). It has been reported that some anti-MOMP monoclonal antibodies specific for serovar (Caldwell \& Perry, 1982; Lucero \& Kuo, 1985), subspecies (Lucero \& Kuo, 1985) and species (Peeling et al., 1984) epitopes neutralize chlamydial infectivity, suggesting that these epitopes might be expressed at the surface. The results described here provide direct evidence for the surface exposure of serovar, a number of subspecies and a species epitope on the MOMP of both RBs and EBs. Various other MOMP epitopes were inaccessible in our assay and are presumably located below the membrane surface. Also, MOMP surface exposure appears to be constant throughout the growth cycle suggesting that expression of this protein is important both during intracellular growth, possibly due to MOMP's porin function (Bavoil et al., 1984), and in its extracellular EB form where it may be involved in as yet undefined pathogenic roles during the initiation of infection.

The $60 \mathrm{kDa}$ and $12 \mathrm{kDa}$ chlamydial outer-membrane proteins, like MOMP, appear to be structural proteins that form an extensive protein matrix stabilized by disulphide bonding (Hatch et al., 1986; Newhall, 1987). These proteins are present in EBs but are nearly absent in RBs (Hatch et al., 1984). A study of the antigen specificity of the human immune response has demonstrated that the $60 \mathrm{kDa}$ protein is a significant immunogen during natural genital chlamydial infection (Newhall et al., 1982). Based on this and preliminary results from surface radio-iodination studies we speculated that the $60 \mathrm{kDa}$ protein was probably a surface-exposed protein. In the present study, however, we did not detect $60 \mathrm{kDa}$ or $12 \mathrm{kDa}$ epitopes on EB or RB surfaces of $\mathrm{L}_{2} / 434$ or $\mathrm{F} / \mathrm{UW}-6$ chlamydiae using hyperimmunized mouse anti- $60 \mathrm{kDa}$ polyclonal antisera, monoclonal antibodies specific for three different $60 \mathrm{kDa}$ epitopes (Newhall \& Basinski, 1986), and a single anti-12 kDa monoclonal antibody. We conclude that the epitopes located on the $60 \mathrm{kDa}$ and $12 \mathrm{kDa}$ proteins recognized by our poly- and monoclonal antibodies are not located at the bacterial surface and are either located in the membrane interior or on the inner surface of the outer membrane, or may be at the outer surface but inaccessible due to steric blockage by other membrane components. Interestingly, an antibody specific for another potent immunogen during natural genital infection, the $62 \mathrm{kDa}$ protein, also did not react with the chlamydial surface. The location of this protein within an intact cell is also unknown.

The $15 \mathrm{kDa}$ and $29 \mathrm{kDa}$ proteins recognized by our monoclonal antibody appear to be equivalent to the $18 \mathrm{kDa}$ and $32 \mathrm{kDa}$ proteins recently described by Hackstadt (1986) and Wenman \& Meuser (1986), which bind to eukaryotic cell surfaces (Hackstadt \& Newhall, unpublished). These proteins are present primarily in the EB rather than the RB outer membrane. They bind to HeLa cell-membrane components, and stimulate the formation in rabbits of antibody that appears to possess neutralizing ability (Hackstadt, 1986; Wenman \& Meuser, 1986). However, the $18 \mathrm{kDa}$ and $32 \mathrm{kDa}$ proteins were labelled poorly by surface radioiodination methods (Hackstadt, 1986). Also, our IEM data indicate that the epitope recognized by the monoclonal antibody specific for the $15 \mathrm{kDa}$ and $29 \mathrm{kDa}$ proteins is not accessible to antibody on the surfaces of EBs or RBs of either strain tested. Consequently, additional work will be necessary to determine whether these are surface-exposed proteins. 
The chlamydial genus-reactive antigen recognized by our putative anti-LPS monoclonal antibodies migrates with the tracking dye on a conventional SDS $/ 10 \%(w / v)$ polyacrylamide gel, is sensitive to periodate oxidation but insensitive to proteases, and possesses other characteristics attributed to the chlamydial equivalent of bacterial LPS, including the presence of ketodeoxyoctonic acid and the ability to gel Limulus amoebocyte lysate (Wilde et al., 1986). Chlamydial LPS has at least three antigenic domains, two shared with other Gram-negative bacteria and one unique to chlamydia (Caldwell \& Hitchcock, 1984). The genus-specific antigen is present throughout the chlamydial growth cycle (Reeve \& Traverne, 1962), and has been detected on the surfaces of infected cells (Wilde et al., 1986), on the processes of uninfected cells adjacent to an infected cell (Richmond \& Stirling, 1981; Wilde et al., 1986) and in the medium surrounding infected cells (Reeve \& Traverne, 1962). The exact mechanism of LPS release from chlamydia is unknown, although evidence suggests that RBs may shed membrane, possibly containing LPS, in the form of membrane blebs (Stirling \& Richmond, 1980). Previous IEM studies that used an antiserum having genus specificity demonstrated reactive antigens on blebs, RBs and EBs (Richmond \& Stirling, 1981). Whether the reactive antigens include LPS is not clear. Nevertheless, data from microimmunofluorescence tests (Stephens et al., 1982; Yong et al., 1979) and ELISA (Jones et al., 1983) suggest that genus-specific LPS antigen is more readily detected on RBs than on EBs. Additional evidence that LPS is not exposed to a large extent on the surface of EBs has been obtained by Kuo \& Chi (1987), using a different immunogold method from that described here. In comparison, our IEM data indicated that LPS is integrated in the RB outer membrane such that at least part of the molecule is accessible to antibody, while the same LPS moiety or moieties is not exposed on the EB surface. The density of LPS epitopes detected on RB surfaces using our system approximated that seen for MOMP, while EB surfaces were clearly not labelled. Thus, there appear to be fundamental structural differences between RB and EB surfaces, and these may be reflective of the EB-associated properties of infectivity and increased stability.

In conclusion, MOMP was the only outer-membrane component detected on the EB surface. All known MOMP immunological determinants except a genus-reactive, one species-reactive, and one subspecies-reactive epitope were surface exposed. The RB, on the other hand, had LPS as well as all of the EB antibody-accessible epitopes exposed on its surface. These observations were identical for both an $\mathrm{LGV}\left(\mathrm{L}_{2} / 434 / \mathrm{Bu}\right)$ and a trachoma $(\mathrm{F} / \mathrm{UW}-6 / \mathrm{Cx})$ strain of $C$. trachomatis.

This investigation was supported by Public Health Service grant AI-20110 from the National Institute of Allergy and Infectious Diseases.

\section{REFERENCES}

Barbour, A. G., Amano, K.-I., Hackstadt, T., Perry, L. \& Caldwell, H. D. (1982). Chlamydia trachomatis has penicillin-binding proteins but not detectable muramic acid. Journal of Bacteriology 151, 420-428.

Barenfanger, J. \& MacDonald, A. B. (1974). The role of immunoglobulin in the neutralization of trachoma infectivity. Journal of Immunology 113, 1607-1617.

Batteiger, B. E., Newhall, V, W. J., Terho, P., WILDE, III, C. E. \& JoNES, R. B. (1986). Antigenic analysis of the major outer membrane protein of Chlamydia trachomatis with murine monoclonal antibodies. Infection and Immunity 53, 530-533.

BavoIL, P., OHLIN, A. \& SchachTER, J. (1984). Role of disulfide bonding in outer membrane structure and permeability in Chlamydia trachomatis. Infection and Immunity 44, 479-485.

BEESLEY, J. E. (1984). Recent advances in microbiological immunocytochemistry. In Immunolabelling for
Electron Microscopy, pp. 289-303. Edited by J. M. Polak \& I. M. Varndell. Amsterdam: Elsevier Science Publishers.

BeEsley, J. E., DAY, S. E. J., BetTS, M. P. \& ThoRley, C. M. (1984). Immunocytochemical labelling of Bacteroides nodosus pili using an immunogold technique. Journal of General Microbiology 130, 14811487.

Benson, J. R. \& HARE, P. E. (1975). $O$-phthalaldehyde: fluorogenic detection of primary amines in the picomole range. Comparison with fluorescamine and ninhydrin. Proceedings of the National Academy of Sciences of the United States of America 72, 619622.

Byrne, G. I. \& Moulder, J. W. (1978). Parasitespecified phagocytosis of Chlamydia psittaci and Chlamydia trachomatis by $\mathrm{L}$ and HeLa cells. Infection and Immunity 19, 598-606.

Caldwell, H. D. \& Hrtchcock, P. J. (1984). Monoclonal antibody against a genus-specific anti- 
gen of Chlamydia species: location of the epitope on chlamydial lipopolysaccharide. Infection and Immunity 44, 306-314.

Caldwell, H. D. \& Perry, L. J. (1982). Neutralization of Chlamydia trachomatis infectivity with antibodies to the major outer membrane protein. Infection and Immunity 38, 745-754.

Caldwell, H. D., Kromhout, J. \& Schachter, J. (1981). Purification and partial characterization of the major outer membrane protein of Chlamydia trachomatis. Infection and Immunity 31, 1161-1176.

Clark, R. B., Nachamkin, I., Schatzki, P. F. \& DALToN, H. P. (1982). Localization of distinct surface antigens of Chlamydia trachomatis HAR-13 by immune electron microscopy with monoclonal antibodies. Infection and Immunity 38, 1273-1278.

EISSENBERG, L. G. \& WYRICK, P. B. (1981). Inhibition of phagolysosome fusion is localized to Chlamydia psittaci-laden vacuoles. Infection and Immunity 32, 889-896.

EissenberG, L. G., Wyrick, P. B., Davis, C. H. \& RuMPP, J. W. (1983). Chlamydia psittaci elementary body envelopes: ingestion and inhibition of phagolysosome fusion. Infection and Immunity 40, 741-751.

FRIIS, R. R. (1972). Interaction of $\mathbf{L}$ cells and Chlamydia psittaci: entry of the parasite and host responses to its development. Journal of Bacteriology 110, 706-721.

HACKsTaDT, T. (1986). Identification and properties of chlamydial polypeptides that bind eucaryotic cell surface components. Journal of Bacteriology 165, 1320.

Hackstadt, T. \& Caldwell, H. D. (1985). Effect of proteolytic cleavage of surface-exposed proteins on infectivity of Chlamydia trachomatis. Infection and Immunity 48, 546-551.

Hatch, T. P., Allan, I. \& Pearce, J. H. (1984). Structural and polypeptide differences between envelopes of infective and reproductive life cycle forms of Chlamydia spp. Journal of Bacteriology 157, 13-20.

Hatch, T. P., Miceli, M. \& Sublett, J. E. (1986). Synthesis of disulfide-bonded outer membrane proteins during the developmental cycle of Chlamydia psittaci and Chlamydia trachomatis. Journal of Bacteriology 165, 379-385.

Jones, R. B., Bruins, S. C. \& Newhall, V, W. J. (1983). Comparison of reticulate and elementary body antigens in detection of antibodies against Chlamydia trachomatis by an enzyme-linked immunosorbent assay. Journal of Clinical Microbiology 17, 466-471.

Kuo, C.-C. \& CHI, E. Y. (1987). Ultrastructural study of Chlamydia trachomatis surface antigens by immunogold staining with monoclonal antibodies. Infection and Immunity 55, 1324-1328.

Kuo, C.-C. \& Grayson, J. T. (1976). Interaction of Chlamydia trachomatis organisms and HeLa 229 cells. Infection and Immunity 13, 1103-1109.

LAWN, A. M., BLYTH, W. A. \& TAVERNe, J. (1973). Interactions of TRIC agents with macrophages and BHK-21 cells observed by electron microscopy. Journal of Hygiene 71, 515-528.

LEVY, N. J. \& MOULDER, J. W. (1982). Attachment of cell walls of Chlamydia psittaci to mouse fibroblasts (L cells). Infection and Immunity 17, 1059-1065.
LuCERo, M. E. \& Kuo, C.-C. (1985). Neutralization of Chlamydia trachomatis cell culture infection by serovar-specific monoclonal antibodies. Infection and Immunity 50, 595-597.

Mouton, C. \& LAMONDE, L. (1984). Immunogold electron microscopy of surface antigens of oral bacteria. Canadian Journal of Microbiology 30, 1008 1013.

Newhall, V, W. J. (1987). Biosynthesis and disulfide cross-linking of outer membrane components during the growth cycle of Chlamydia trachomatis. Infection and Immunity 55, 162-168.

Newhall, V, W. J. \& BASINSKI, M. B. (1986). Purification and structural characterization of chlamydial outer membrane proteins. In Chlamydial Infections, pp. 93-96. Edited by D. Oriel, F. Ridgway, J. Schachter, D. Taylor-Robinson and M. Ward. Cambridge: Cambridge University Press.

Newhall, V, W. J., Batteiger, B. \& Jones, R. B. (1982). Analysis of the human serological response to proteins of Chlamydia trachomatis. Infection and Immunity 38, 1181-1189.

Newhall, V, W. J., Mail, L. B., Wilde, III, C. E. \& JONES, R. B. (1985). Purification and antigenic relatedness of proteins II of Neisseria gonorrhoeae. Infection and Immunity 49, 576-580.

Newhall, V, W. J., Terho, P., Wilde, III, C. E., BAtTeiger, B. E. \& Jones, R. B. (1986). Serovar determination of Chlamydia trachomatis isolates by using type-specific monoclonal antibodies. Journal of Clinical Microbiology 23, 333-338.

Peeling, R., Maclean, I. W. \& Brunham, R. C. (1984). In vitro neutralization of Chlamydia trachomatis with monoclonal antibody to an epitope on the major outer membrane protein. Infection and Immunity 46, 484-488.

REEVE, P.\& TAVERNE, J. (1962). Some properties of the complement-fixing antigens of trachoma and inclusion blenorrhea and the relationship of the antigens to the development cycle. Journal of General Microbiology 27, 501-508.

RichMond, S. J. \& STIRLING, P. (1981). Localization of chlamydial group antigen in McCoy cell monolayers infected with Chlamydia trachomatis or Chlamydia psittaci. Infection and Immunity 34, 561-570.

Robinson, JR, E. N., McGee, Z. A., Kaplan, J., Hammond, M. E., LaRson, J. K., Buchanan, T. M. \& SchoolNIK, G. K. (1984). Ultrastructural localization of specific gonococcal macromolecules with antibody-gold sphere immunological probes. Infection and Immunity 46, 361-366.

Salari, S. H. \& Ward, M. E. (1981). Polypeptide composition of Chlamydia trachomatis. Journal of General Microbiology 123, 197-207.

STEPHENS, R. S., TAM, M. R., KUO, C.-C. \& NowinsKI, R. C. (1982). Monoclonal antibodies to Chlamydia trachomatis : antibody specificities and antigen characterization. Journal of Immunology 128, 1083-1089.

Stirling, P. \& Richmond, S. J. (1980). Production of outer membrane blebs during chlamydial replication. FEMS Microbiology Letters 9, 103-105.

WANG, S.-P. \& Grayston, J. T. (1971). Classification of TRIC and related strains with microimmunofluorescence. In Trachoma and Related Disorders Caused by Chlamydial Agents, pp. 305-321. Edited by R. L. Nichols. Amsterdam: Excerpta Medica. 
Ward, M. E. \& MurRay, A. (1984). Control mechanisms governing the infectivity of Chlamydia trachomatis for HeLa cells: mechanisms of endocytosis. Journal of General Microbiology 130, 1765-1780.

Wenman, W. M. \& Meuser, R. U. (1986). Chlamydia trachomatis elementary bodies possess proteins which bind to eucaryotic cell membranes. Journal of Bacteriology 165, 602-607.

WILDE, III, C. E., KARIMI, S. T. \& HAAK, R. A. (1986). Cell surface alterations during chlamydial infection. In Microbiology - 1986, pp. 96-98. Washington, DC: American Society for Microbiology.
Williams, W. D., Schachter, J., Grubbs, B. \& SumaYa, C. V. (1982). The role of antibody in host defense against the agent of mouse pneumonitis. Journal of Infectious Diseases 145, 200-205.

Yong, E. C., ChinN, J. S., Caldwell, H. D. \& Kuo, C.-C. (1979). Reticulate bodies as single antigen in Chlamydia trachomatis serology with microimmunofluorescence. Journal of Clinical Microbiology 10, 351-356. 